\title{
DURATION OF PASSIVE IMMUNITY
}

\author{
By A. T. GLENNY AND BARBARA E. HOPKINS. \\ (Wellcome Physiological Research Laboratories, Beckenham, Kent.) \\ PART IV.
}

(With Charts XVII-XXI.)

PART II of this paper dealt with the rate of disappearance of antitoxic horse serum from normal rabbits ; this present section deals with the rate of disappearance of antitoxic horse serum after injection into rabbits previously sensitised to horse serum. A few cases of serum sensitised rabbits have already been reported; Part I (Table III) recorded the results of injecting antitoxic horse serum into seven rabbits sensitised from 3 to 11 months previously with one or more injections of $1 / 100$ th c.c. or more of horse serum. The conclusions drawn were that the course of elimination of antitoxin followed the same three phases that occur when antitoxic horse serum is eliminated from normal rabbits, but that Phase $\mathrm{C}$ occurred earlier and was more rapid. In Part II (Table VII) we showed that similar rates of loss occurred in three rabbits sensitised six or seven weeks earlier with 0.5 c.c. of horse serum, and Table VI recorded the results of experiments on two rabbits which received their second injection 10 and 11 days after the first; in these two rabbits the usual phases were to a certain extent masked by residual precipitin formed in excess in response to the previous injection. A number of results in Part II also suggested that apparently normal rabbits had become naturally sensitised to horse serum; it was of interest therefore to determine the sensitising effect of various amounts of horse serum. As a preliminary experiment four rabbits were injected subcutaneously with $1 / 100,000$ th c.c., $1 / 1000$ th c.c., 1/10th c.c. nd 10 c.c. of horse serum, and four weeks later injected intravenously with antitoxic horse serum; the curves of subsequent antitoxic content were then plotted. The results obtained are recorded in Tables XXXV and XXXVI and Curves $65-68$ on Chart XVII. The exceptional Phase A loss shown by rabbit 65 is probably due to an error in titrating the sample of blood taken 15 minutes after injection; calculation from the weight of the rabbit would give the antitoxic value as $8 \cdot 1$ units and would thus reduce the Phase A loss to 53.7 per cent. The four rabbits exhibit a progressive rate of elimination or increasing degree of sensitisation in accordance with the volume of the sensitising dose. Rabbit 66 was definitely sensitised by a subcutaneous injection of $1 / 1000$ th c.c. of horse serum but rabbit 65 that had received 1/100th of this amount did not give so conclusive a result. Table XXXVII has been compiled to show the number of days taken for the 


\section{TABLE XXXV.}

Showing the antitoxic value of four rabbits, previously sensitised with different quantities of horse serum, at different intervals of time after the intravenous injection of 0.5 c.c. of unconcentrated horse serum containing 750 units diphtheria antitoxin.

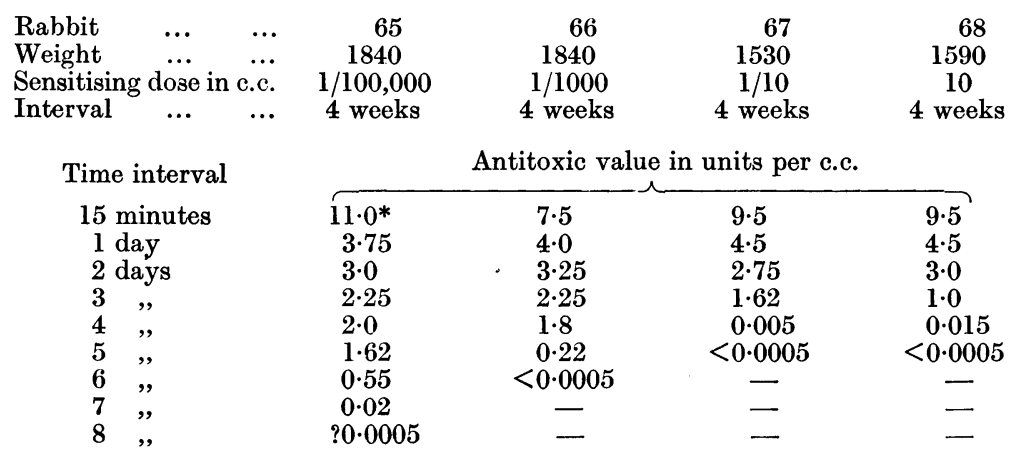

* This reading is probably incorrect; the antitoxic value calculated from the weight of the rabbit is $8 \cdot 1$ units per c.c.

\section{TABLE XXXVI.}

Showing the percentage daily loss in antitoxic value of the blood of four rabbits previously sensitised with different quantities of horse serum, at different intervals of time after the intravenous injection of 0.5 c.c. of unconcentrated horse serum containing 750 units diphtheria antitoxin.

\begin{tabular}{|c|c|c|c|c|c|c|c|c|}
\hline \multirow{3}{*}{$\begin{array}{c}\text { Time } \\
\text { interval } \\
0-1 \text { day } \\
\text { 1-2 days }\end{array}$} & \multicolumn{2}{|c|}{ Rabbit 65} & \multicolumn{2}{|c|}{ Rabbit 66} & \multicolumn{2}{|c|}{ Rabbit 67} & \multicolumn{2}{|c|}{ Rabbit 68} \\
\hline & $65.9 *$ & Phase A & $46 \cdot 7$ & Phase A & $52 \cdot 6$ & Phase A & $52 \cdot 6$ & Phase A \\
\hline & $20 \cdot 0$ ) & & $18 \cdot 7$ ) & Phase $\mathrm{B}$ & 38.9 & Phase B & $33 \cdot 3$ & Phase B \\
\hline $2-3$, & 25.0 & Phase B & $30 \cdot 7\}$ & Thase is & $40 \cdot 1$ & Av. 39.5 & $66 \cdot 7$ ) & Phase C \\
\hline $3-4 \quad$, & $11 \cdot 1$ & Av. $18 \cdot 8$ & $20 \cdot 0)$ & $23 \cdot 1$ & $99 \cdot 7$ & Phase C & $98.5\}$ & Av. $82 \cdot 6$ \\
\hline 4-5 & $19 \cdot 0)$ & & $87 \cdot 7$ & Phase C & & - & & - \\
\hline $5-6$ & $66 \cdot 0$ & Phase C & & - & & - & & - \\
\hline 6-7 , & $96 \cdot 3\}$ & Av. $81 \cdot 1$ & & - & & 一 & & - \\
\hline
\end{tabular}

* The observed value for the antitoxic content on the first day was probably too high (see footnote to previous table); the calculated value gives a Phase $A$ loss of $53.7 \%$.

\section{TABLE XXXVII.}

Showing the number of days taken for the antitoxic content of the rabbits recorded in Tables $X X X V$ and $X X X V I$ to fall below various stated fractions of the total amount injected.

$\begin{array}{ccccccc}\text { Rabbit } & \begin{array}{c}\text { Serum } \\ \text { injected }\end{array} & \text { Weight } & 1 / 10 & 1 / 100 & 1 / 1000 & 1 / 10,000 \\ 65 & \text { Horse } & 1840 & 6 & 7 & 8 & \mathbf{8} \\ 66 & \# & 1840 & 5 & 6 & 6 & 6 \\ 67 & \#, & 1530 & 4 & 4 & 4 & 5 \\ 68 & \text { ", } & 1590 & \mathbf{4} & \mathbf{4} & \mathbf{5} & \mathbf{5}\end{array}$


antitoxic content of these rabbits to fall below 1/10th, 1/100th, 1/1000th and $1 / 10,000$ th of the amount injected. A comparison between Table XXXVII and Table XIX in Part II shows that rabbit 65 eliminated antitoxin more quickly than the majority of normal rabbits. Omitting rabbits over $2 \frac{1}{2}$ kilos, out of 19 rabbits recorded, in only one (the exceptional case of rabbit 94) had the antitoxic content fallen to $1 / 100$ th or $1 / 1000$ th earlier than in rabbit 65 and only one other rabbit reached either level in such short time. The $1 / 10,000$ th level was reached by rabbit 65 in less time than that taken by any other rabbit of the same weight or less. The degree of responsiveness of this rabbit resembled that of rabbits weighing $2 \frac{1}{2}$ kilos or more. The high rate of percentage loss during Phase $\mathrm{B}$ in rabbits 67 and 68 in Table XXXV, indicated also by the steepness of that section of the curves on Chart XVII, may be taken as showing that excess

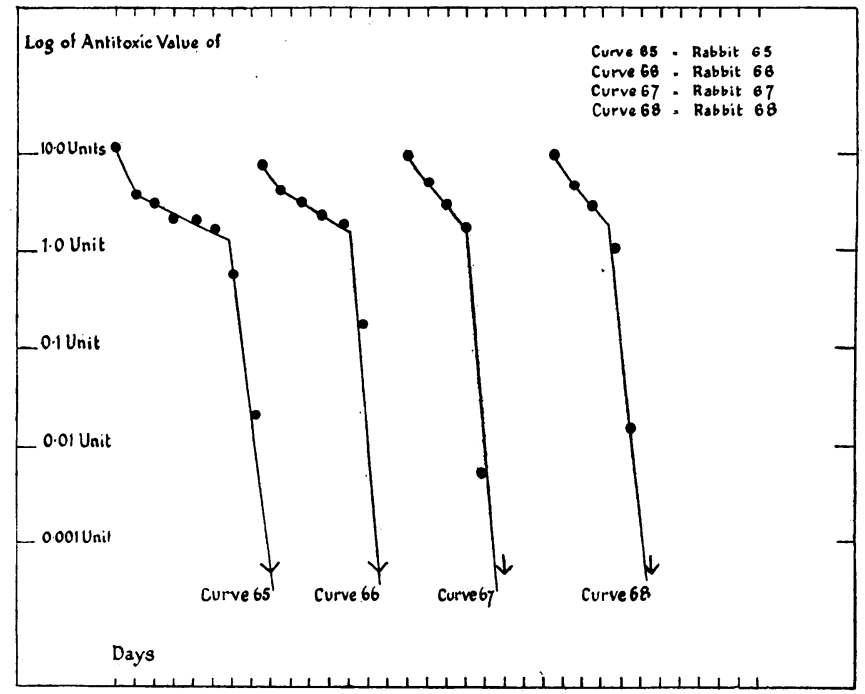

Chart XVII

precipitin was present four weeks after a first injection of 1/10th c.c. and a first injection of 10 c.c. of horse serum respectively. It would appear from this experiment that so small a dose as 0.00001 c.c. of horse serum causes an appreciable degree of active immunity to horse serum, but more experiments would be needed definitely to confirm this statement.

The next experiments were designed to show the progressive sensitisation that occurs after a series of injections of horse serum into rabbits. Table XXXVIII shows the course of elimination of antitoxic horse serum after each of four intravenous injections in two different sensitised rabbits, 13 and 33 . The first injections were given nine and six months respectively after the last small sensitising dose; the curves of resultant antitoxic content after the first injection have already been published in Part I (Curves 4 and 7 on Chart II). On re-injection five weeks later, rabbit 13 lost $74 \cdot 1$ per cent. of antitoxin 
within the first 24 hours and all antitoxin injected was lost in three or four days. It must be pointed out here that the base line in the charts relating to the sensitised rabbits recorded is not always zero because there may be some degree of active immunity to diphtheria present. (The rabbits used had received injections of toxin antitoxin mixtures and were thus actively immune to diphtheria toxin and sensitive to horse serum.) Thus the antitoxic value of rabbit 13 before the first injection here recorded was 0.005 unit per c.c. as the result of active immunity produced by some earlier stimulus; later the degree of residual active immunity had fallen to 0.003 unit per c.c. Six weeks after the second injection of 0.5 c.c. of antitoxic horse serum there was sufficient residual precipitin present immediately to eliminate 50 per cent. of the horse serum then injected. Fifteen minutes after the injection the antitoxic value of the blood was less than 50 per cent. of that calculated according to the weight of the rabbit, and 24 hours later only 0.1 per cent. remained. The fourth

\section{TABLE XXXVIII.}

Showing the antitoxic value of two sensitised rabbits, after a series of four intravenous injections of 0.5 c.c. of unconcentrated horse serum containing 750 units diphtheria antitoxin.

\begin{tabular}{|c|c|c|c|c|c|c|c|c|}
\hline \multirow{2}{*}{$\begin{array}{l}\text { Rabbit ... } \\
\begin{array}{l}\text { Interval since pre- } \\
\text { vious injection }\end{array}\end{array}$} & \multicolumn{4}{|c|}{13} & \multicolumn{4}{|c|}{33} \\
\hline & 9 mths. & 5 wks. & 6 wks. & 6 days & $6 \mathrm{mths}$. & 3 wks. & 10 wks. & 6 days \\
\hline Time interval & \multicolumn{8}{|c|}{ Antitoxic value in units per c.c. } \\
\hline 15 minutes & $5 \cdot 0$ & $6 \cdot 75$ & $2 \cdot 5$ & $3 \cdot 0$ & $8 \cdot 0$ & $8 \cdot 0$ & $9 \cdot 5$ & 0.02 \\
\hline 1 day & - & $1 \cdot 75$ & 0.006 & $0 \cdot 003$ & $4 \cdot 5$ & $1 \cdot 1$ & $2 \cdot 75$ & 0.003 \\
\hline 2 days & $2 \cdot 5$ & $1 \cdot 1$ & -0.003 & - & $3 \cdot 5$ & 0.45 & $1 \cdot 6$ & 0.0015 \\
\hline 3 ," & $1 \cdot 6$ & - & - & - & $2 \cdot 25$ & 0.02 & 0.0015 & - \\
\hline 4 & 0.005 & 0.005 & - & 一 & 0.03 & - & 一 & - \\
\hline 5, & - & - & - & - & - & 一 & - & - \\
\hline $6 \%$ & - & - & - & - & - & - & - & - \\
\hline 7 , & 一 & - & - & 一 & - & 一 & 一 & - \\
\hline
\end{tabular}

injection was given six days after the last and again rapid elimination occurred and no passive immunity remained 24 hours after injection.

Very similar results were obtained with rabbit 33. After the second injection, 86.2 per cent. of the antitoxin was lost in the first day and all passive immunity had disappeared by the third day. Rapid loss also occurred after the third injection given ten weeks after the second. Six days later the horse serum injected was eliminated at so great a pace that only $1 / 400$ th of that injected could be detected within 15 minutes of the injection.

A similar experiment recorded in Tables XXXIX and XL, was carried out on two other rabbits, 38 and 54, but the subsequent injections of horse serum were given subcutaneously. Rabbit 38 had already received an intravenous injection of 0.5 c.c. of antitoxic horse serum as recorded in Table III, Part I. Three weeks later the same amount was injected subcutaneously and the highest antitoxic concentration in the blood, reached two days later, was 0.05 unit per c.c., $1 / 50$ th of the value that a normal rabbit would exhibit 
at the same interval of time after a similar injection. Six days later ten times as much antitoxic horse serum was injected and the highest value reached, again on the second day, was $1 / 10$ th that of the previous occasion, or $1 / 5000$ th of the value a normal rabbit would have possessed. The effect of the injection apparently was to use up much of the residual precipitin without acting strongly as a secondary stimulus, because the next subcutaneous injection given four weeks later resulted in a much higher titre. The maximum value recorded, on the third day, was little less than 1/10th

\section{TABLE XXXIX.}

Showing the antitoxic value of a sensitised rabbit after a series of subcutaneous injections of unconcentrated horse serum containing diphtheria antitoxin.

\section{Rabbit 38}

Previous history Two sensitising doses subcutaneously of 0.013 c.c. followed three months later Interval since pre-

vious injection
No. of units injected
Two sensitising doses subcutaneously of 0.013 c.c.
by 0.5 c.c. intravenously

No. of units injected

$\begin{array}{ccccc}3 \text { weeks } & 6 \text { days } & 4 \text { weeks } & 4 \text { weeks } & 5 \text { days } \\ 750 & 7500 & 7500 & 7500 & 7500\end{array}$

Time interval

1 day

2 days

3 ,

4,

5 ,

6 "

Antitoxic value in units per c.c.

\begin{tabular}{lllll}
\hline 0.004 & 0.00015 & 0.04 & 0.003 & 0.04 \\
0.05 & 0.005 & 1.75 & 0.003 & 0.022 \\
0.001 & 0.005 & 2.0 & 0.0012 & 0.0015 \\
- & 0.0018 & 0.002 & - & 0.0005 \\
- & 0.0012 & - & 0.0005 & - \\
- & 0.0008 & 0.001 & - & -
\end{tabular}

TABLE XL.

Showing the antitoxic value of a sensitised rabbit after a series of subcutaneous injections of unconcentrated horse serum containing diphtheria antitoxin.

\section{Rabbit 54}

Previous history

Interval since previous injection

No. of units injected

Time interval

1 day
2 days
3 ",
4 ",
6 ",
One sensitising dose intravenously of 0.025 c.c.

5 weeks $\quad 7$ weeks $\quad 5$ days

$\begin{array}{lll}750 & 7500 & 7500\end{array}$

\begin{tabular}{lcl}
$2 \cdot 5$ & \multicolumn{3}{c}{ Antitoxic value in units per c.c. } \\
$2 \cdot 75$ & $18 \cdot 0$ & $2 \cdot 25$ \\
$3 \cdot 75$ & $30 \cdot 0$ & $3 \cdot 0$ \\
1.9 & $25 \cdot 0$ & $2 \cdot 75$ \\
0.005 & - & $2 \cdot 0$ \\
$<0.0005$ & Reinjected & Killed
\end{tabular}

of the titre expected from a normal rabbit. Subsequent injections, four weeks and again five days later, resulted in very low titres. This rapid elimination of antitoxin is of great importance clinically if man becomes sensitive to horse serum as readily as the rabbit. It is pointed out that rabbit 38, after two small subcutaneous injections of horse serum followed three months later by an intravenous injection of 0.5 c.c. horse serum and again three weeks later by a further injection of 0.5 c.c. subcutaneously, was so sensitive six days after the last injection that the highest concentration in the blood, after a sub- 
cutaneous injection of 5 c.c. of horse serum, represented only $1 / 15,000$ th of the total antitoxin injected. A later injection after an interval of four weeks from the previous one, showed no higher value. The results following the third subcutaneous injection of this rabbit are of particular interest, and would appear to indicate that all residual precipitin was used up in eliminating the majority of the antitoxin absorbed into the circulation during the first day, for during the next two days absorption was normal, and then further production of precipitin was stimulated.

Rabbit 54 was in an earlier stage of immunity to horse serum; the course of elimination of antitoxin after the first two injections recorded may be considered as typical for subcutaneous injections into sensitised rabbits. The antitoxic content after the next injection of 7500 units given five days after the previous injection, was so reduced by excess precipitin that the values recorded corresponded very closely with those following the first injection when only 750 units were given.

The next case to be considered concerns a rabbit, number 61 , injected intravenously with 0.5 c.c. of antitoxic horse serum at intervals of approximately a week. Tables XLI and XLII record the antitoxic content and rate of loss after each of a series of nine injections. The first eight injections were of the same amount, but at the last injection one-tenth of the usual quantity was given. The speed of elimination was sufficiently rapid after the last two injections for the 15 minute reading to be below the theoretical value. After the first three injections over 90 per cent. of antitoxin present immediately after injection was lost during the subsequent 24 hours. Curves 69 to 77 on Chart XVIII show graphically the rapidity of elimination after each injection. Each curve suggests a large initial loss which uses up most of the excess precipitin from the previous injection, and is then followed by a Phase B loss accelerated by continued precipitin formation. Curves 70 and 71 and possibly 73 exhibit all three phases, but the other injections appear all to have been lost before Phase $\mathrm{C}$ commenced. It is significant that in no instance was all antitoxin eliminated within the first 24 hours. In most instances 98 per cent. of the 750 units injected was lost within 24 hours; when only 75 units were injected the first day loss was again 98 per cent. of the amount injected.

Rabbit 48 recorded in Table XLIII was injected intravenously every day with 0.5 c.c. of antitoxic horse serum for 16 days, and then at irregular intervals during the next week. On the twenty-fourth day of the experiment the animal received its twentieth and last injection of antitoxic serum, but the same volume of normal horse serum was administered on six occasions during the next seven days. Many factors are involved in this experiment, and the issues are not very clear, but a number of interesting points may be gathered from a detailed consideration of Table XLIII and Chart XIX. The first injection is followed by the usual 50 per cent. loss due to Phase A; if the curve of elimination of the antitoxin given at each injection follows an independent course, then, for each dose of antitoxin in turn, Phase A will be succeeded 
by Phase B, which will continue until Phase C, induced by the first injection, interferes with the total antitoxic content. Thus, assuming Phase $\mathrm{A}$ to be approximately 50 per cent. and Phase B to be approximately 25 per cent., then for every 100 units injected the second day content would be 50 before injection and 150 after injection. Before the third injection there would remain 37 units from the first injection and 50 from the second. The following

\section{TABLE XLI.}

Showing the antitoxic value of a rabbit after a series of intravenous injections, given at short intervals of time, of unconcentrated horse serum containing diphtheria antitoxin.

\section{Rabbit 61}

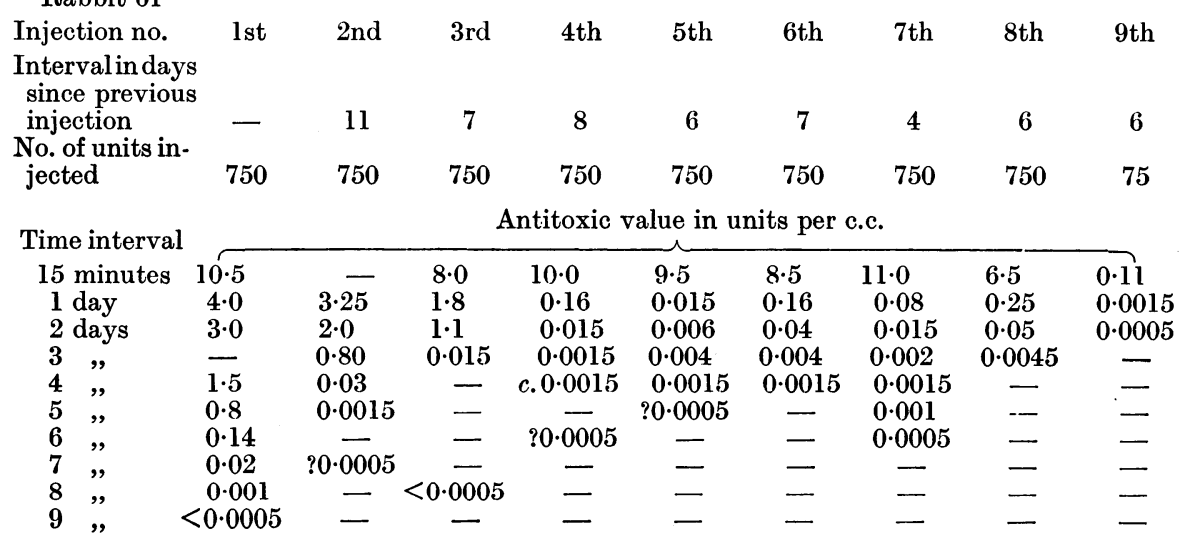

\section{TABLE XLII.}

Showing the percentage daily loss in antitoxic value of a rabbit after a series of intravenous injections given at short intervals of time, of unconcentrated horse serum containing diphtheria antitoxin.

\begin{tabular}{|c|c|c|c|c|c|c|c|c|c|}
\hline \multicolumn{10}{|l|}{$\begin{array}{l}\text { Injection no. } \\
\text { Time interval }\end{array}$} \\
\hline $0-1$ day & 61.9 & - & $77 \cdot 5$ & 98.4 & $99 \cdot 8$ & $98 \cdot 1$ & $99 \cdot 3$ & $96 \cdot 2$ & $98 \cdot 6$ \\
\hline 1-2 days & $25 \cdot 0$ & 38.5 & $38 \cdot 9$ & $90 \cdot 6$ & $60 \cdot 0$ & $75 \cdot 0$ & $81 \cdot 2$ & $80 \cdot 0$ & $66 \cdot 6$ \\
\hline $2-3 \quad$, & - & $60 \cdot 0$ & $98 \cdot 6$ & $90 \cdot 0$ & $33 \cdot 3$ & $90 \cdot 0$ & $86 \cdot 7$ & $91 \cdot 0$ & - \\
\hline $3-4 \quad$ & $29 \cdot 3$ & $96 \cdot 2$ & - & - & $62 \cdot 5$ & 62.5 & $25 \cdot 0$ & - & - \\
\hline $4-5 \quad "$ & $46 \cdot 7$ & $95 \cdot 0$ & - & - & - & - & $33 \cdot 3$ & - & - \\
\hline $\begin{array}{l}5-6 \\
6-7\end{array}$ & $\begin{array}{l}82 \cdot 5 \\
85 \cdot 7\end{array}$ & E & 二 & 二 & I & 二 & E & 二 & 二 \\
\hline $7-8 \quad$, & $95 \cdot 0$ & - & - & - & - & - & - & - & - \\
\hline 8-9, , & - & - & - & - & - & - & - & - & - \\
\hline
\end{tabular}

day the figure would become 28 for the first, 37 for the second and 50 for the third. Thus the apparent loss for each day would be from 100 to 50 , i.e. 50 per cent., from 150 to 87, i.e. 42 per cent., from 187 to 115 , i.e. 39 per cent., gradually diminishing each day. The actual figures seen after the second, third, fourth and fifth injections are 24 per cent., 32 per cent., 26 per cent. and 32 per cent. Such a rate of loss only slightly in excess of Phase B loss suggests that repeated injection has the effect of paralysing or blocking the Phase A loss. 


\section{TABLE XLIII.}

Showing the antitoxic value of a normal rabbit (number 48) during a series of daily injections of 0.5 c.c. of unconcentrated horse serum containing 750 units diphtheria antitoxin.

\begin{tabular}{|c|c|c|c|c|}
\hline \multirow[b]{2}{*}{ Days } & \multicolumn{3}{|c|}{ Antitoxic value in units per c.c. } & \multirow{2}{*}{$\begin{array}{l}\text { Percentage loss } \\
24 \text { hours after } \\
\text { each injection }\end{array}$} \\
\hline & $\begin{array}{c}\text { Before } \\
\text { injection }\end{array}$ & $\begin{array}{l}15 \text { minutes } \\
\text { after injection }\end{array}$ & Increase & \\
\hline 1 & 0.000 & $10 \cdot 5$ & $10 \cdot 5$ & - \\
\hline 2 & $5 \cdot 5$ & $12 \cdot 5$ & $7 \cdot 0$ & $47 \cdot 6$ \\
\hline 3 & $9 \cdot 5$ & 17.0 & $7 \cdot 5$ & $24 \cdot 0$ \\
\hline 4 & $11 \cdot 5$ & $21 \cdot 0$ & $9 \cdot 5$ & $32 \cdot 3$ \\
\hline 5 & $15 \cdot 5$ & $23 \cdot 0$ & $7 \cdot 5$ & $26 \cdot 2$ \\
\hline 6 & 15.5 & $22 \cdot 0$ & $6 \cdot 5$ & $32 \cdot 6$ \\
\hline 7 & $11 \cdot 0$ & $21 \cdot 0$ & $10 \cdot 0$ & $50 \cdot 0$ \\
\hline 8 & 8.5 & 16.0 & 7.5 & $59 \cdot 5$ \\
\hline 9 & $5 \cdot 5$ & 14.0 & $8 \cdot 5$ & $65 \cdot 6$ \\
\hline 10 & $5 \cdot 0$ & 14.5 & $9 \cdot 5$ & $64 \cdot 3$ \\
\hline 11 & $6 \cdot 5$ & 14.0 & $7 \cdot 5$ & $55 \cdot 2$ \\
\hline 12 & $4 \cdot 8$ & $17 \cdot 0$ & $12 \cdot 2$ & $65 \cdot 7$ \\
\hline 13 & $2 \cdot 75$ & 15.5 & $12 \cdot 75$ & $83 \cdot 8$ \\
\hline 14 & $3 \cdot 5$ & $17 \cdot 0$ & 13.5 & $77 \cdot 4$ \\
\hline 15 & $4 \cdot 0$ & $13 \cdot 0$ & $9 \cdot 0$ & 76.5 \\
\hline 16 & $4 \cdot 5$ & $12 \cdot 0$ & $7 \cdot 5$ & $65 \cdot 4$ \\
\hline 17 & - & - & - & - \\
\hline 18 & $5 \cdot 5$ & $16 \cdot 0$ & $10 \cdot 5$ & $32 \cdot 3$ \\
\hline 19 & $7 \cdot 5$ & $16 \cdot 0$ & $8 \cdot 5$ & $53 \cdot 1$ \\
\hline 20 & - & - & - & - \\
\hline 21 & $11 \cdot 0$ & $18 \cdot 0$ & $7 \cdot 0$ & $17 \cdot 1$ \\
\hline 22 & - & - & - & - \\
\hline 23 & - & - & - & - \\
\hline 24 & $13 \cdot 5$ & $23 \cdot 0$ & $9 \cdot 5$ & $9 \cdot 2$ \\
\hline
\end{tabular}

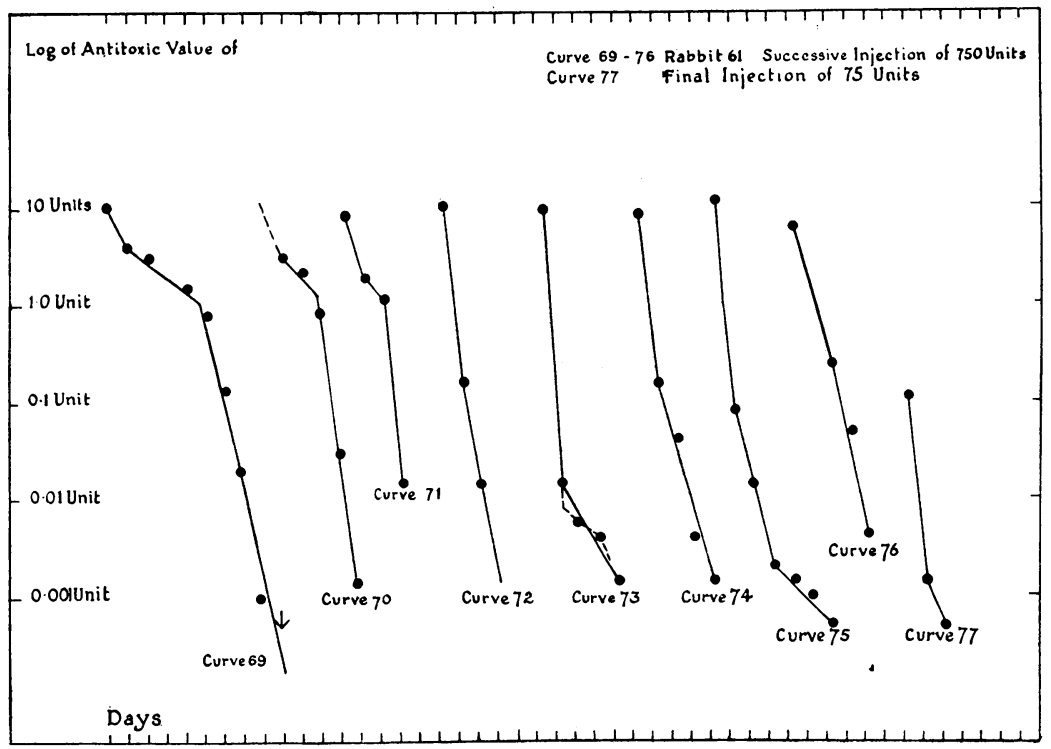

Chart XVIII 
By the seventh day precipitin formation has commenced, and the daily rate of loss increases from 50 per cent. on the seventh day to 83.8 per cent. on the thirteenth day. The antitoxic value of the rabbit on the day after 12 successive daily injections of antitoxin is exactly half the antitoxic value possessed on the day after the first injection. After the thirteenth day the rate of daily loss rapidly diminished, and the curve of antitoxic content again rises while precipitin formation lessens, and after the nineteenth day ceases. It would appear therefore that Phase $\mathrm{C}$ has also been suppressed or prevented. A possible explanation is that the first few injections only may have acted as stimuli, and the injections given during the subsequent period of active antibody production may have failed as stimuli owing to the rapid destruction

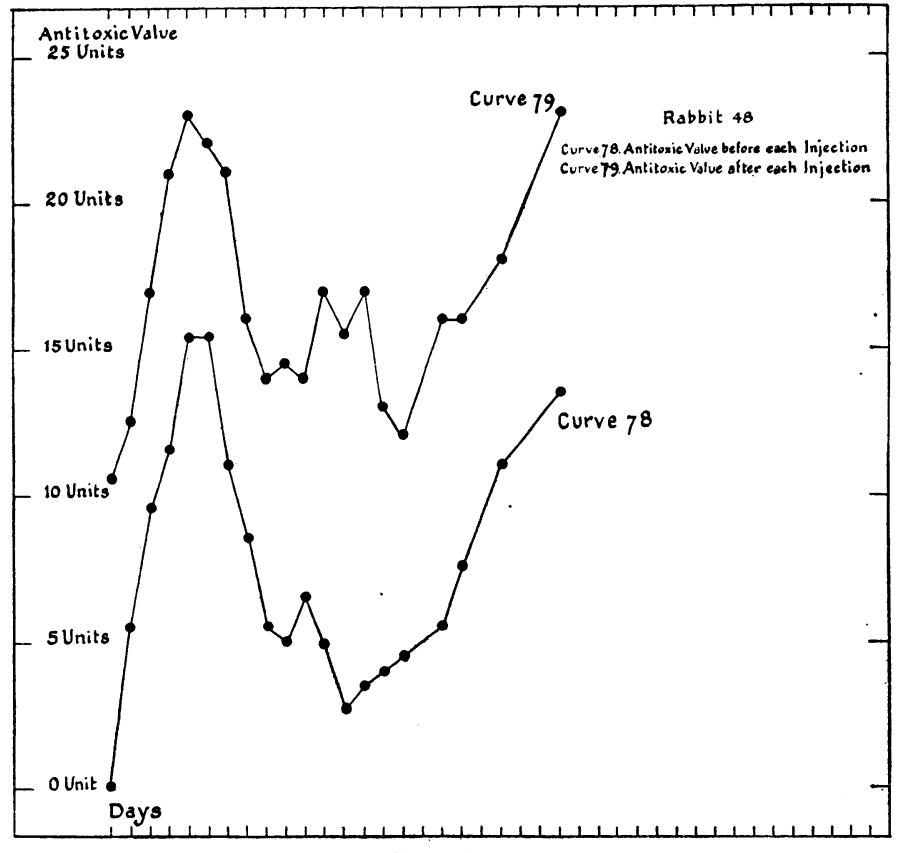

Chart XIX

or elimination of antigen. It is possible, however, that excessive stimulation may have crippled antibody response.

The antitoxic content of rabbit 48 after the last injection of antitoxic horse serum, is traced in Table XLIV and Curve 80 on Chart XX. The daily percentage loss averages 24 per cent. over a period of 40 days, consequently it must be concluded that all loss during the period falls under the heading of Phase $B$.

Comparing rabbit 48 with the previously recorded rabbit 61 , it would appear that a séries of injections of antitoxic horse serum at short intervals of time, such as daily injections, may maintain some degree of passive immunity over a long period; at longer intervals of a week each injection is rapidly lost. 
In the next experiment recorded in Table XLV and Curve 81 on Chart XX a normal rabbit (number 62 ) received only one injection of antitoxic horse

\section{TABLE XLIV.}

Showing the antitoxic value of rabbit 48 at daily intervals after the last of a series of 20 injections of unconcentrated horse serum containing 750 units diphtheria antitoxin.

\begin{tabular}{|c|c|c|}
\hline Days & $\begin{array}{l}\text { Antitoxic value } \\
\text { in units per c.c. }\end{array}$ & $\begin{array}{l}\text { Percentage loss } \\
\text { since previous day }\end{array}$ \\
\hline $1 *$ & 11.5 & $50 \cdot 0$ \\
\hline $2^{*}$ & 8.5 & 26.5 \\
\hline 3 & - & - \\
\hline $4^{*}$ & $5 \cdot 75$ & $17 \cdot 8$ \\
\hline $5^{*}$ & $3 \cdot 75$ & $34 \cdot 8$ \\
\hline $6^{*}$ & $2 \cdot 75$ & $26 \cdot 7$ \\
\hline $7 *$ & $2 \cdot 25$ & $18 \cdot 2$ \\
\hline 8 & - & - \\
\hline 9 & $1 \cdot 75$ & $11 \cdot 8$ \\
\hline 10 & - & - \\
\hline 11 & $1 \cdot 13$ & $19 \cdot 7$ \\
\hline 12 & $0 \cdot 70$ & 38.0 \\
\hline 13 & 0.45 & $35 \cdot 7$ \\
\hline 14 & 0.40 & $11 \cdot 1$ \\
\hline 15 & 0.35 & $12 \cdot 5$ \\
\hline 16 & $0 \cdot 22$ & $37 \cdot 1$ \\
\hline 17 & - & - \\
\hline 18 & $0 \cdot 14$ & $20 \cdot 2$ \\
\hline 19 & - & - \\
\hline 20 & 0.06 & $34 \cdot 5$ \\
\hline
\end{tabular}

$\begin{array}{ccr}\text { Days } & \text { Antitoxic value } & \begin{array}{r}\text { Percentage } \\ \text { in units per c.c. }\end{array} \\ \text { since previo } \\ 21 & 0.055 & 8 \cdot 3 \\ 22 & 0.045 & 18 \cdot 2 \\ 23 & 0.033 & 26 \cdot 7 \\ 24 & - & - \\ 25 & 0.022 & 18 \cdot 4 \\ 26 & 0 \cdot 014 & 36 \cdot 4 \\ 27 & 0.010 & 28 \cdot 6 \\ 28 & - & - \\ 29 & 0.0066 & - \\ 30 & - & - \\ 31 & - & - \\ 32 & - & - \\ 33 & - & - \\ 34 & 0.002 & 10 \cdot 6 \\ 35 & - & - \\ 36 & 0.0016 & - \\ 37 & - & 35 \cdot 4 \\ 38 & 0.0012 & \end{array}$

Average $24 \cdot 3 \%$.

* Injected with 0.5 c.c. normal horse serum, intravenously.

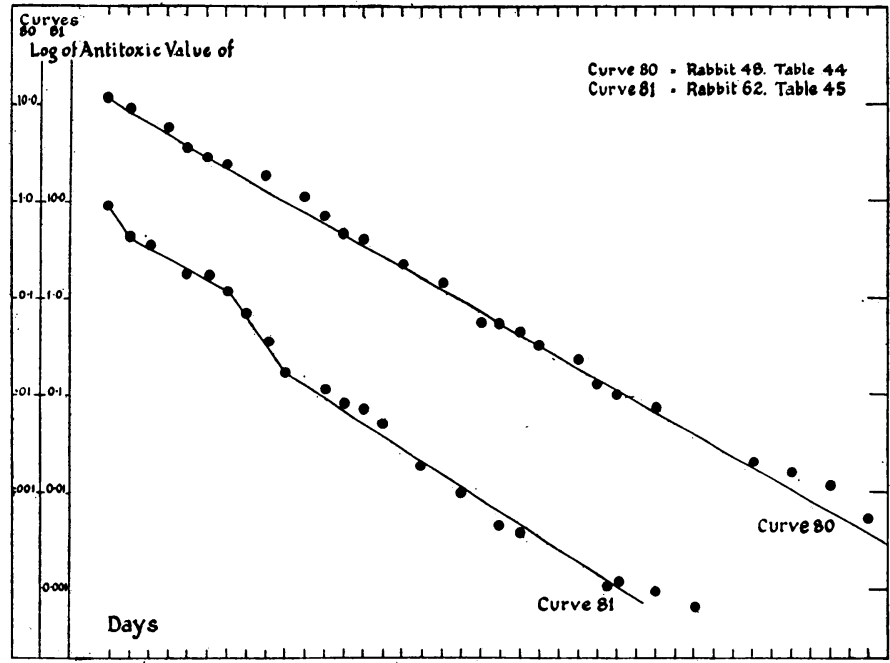

Chart XX

serum followed by daily injections intravenously of 1.0 c.c. of normal horse serum. Phase $\mathrm{A}$ is followed by Phase $\mathrm{B}$ lasting five days and showing an average daily loss of 21 per cent. Phase C, commencing on the seventh day, 
shows an average daily loss of 48.5 per cent.; the small effect is due to the dilution of the antitoxic horse serum by normal serum. After a Phase C, lasting only three days, the percentage daily loss falls to an average of 22.4 per cent. Some degree of Passive Immunity has been maintained for over four weeks by means of daily injections of normal horse serum.

\section{TABLE XLV.}

Showing the antitoxic value of rabbit number 62 at different intervals of time after an intravenous injection of 0.5 c.c. of unconcentrated horse serum containing 750 units diphtheria antitoxin followed by daily intravenous injections of 1.0 c.c. of normal horse serum.

\begin{tabular}{|c|c|c|}
\hline Days & \multicolumn{2}{|c|}{ Injection } \\
\hline 0 & 0.5 c.c. antitoxi & serum \\
\hline 1 & $1 \cdot 0$ c.c. normal & ,, \\
\hline 2 & ," & ," \\
\hline 3 & , & ", \\
\hline 4 & , & , \\
\hline 5 & " & $"$ \\
\hline 6 & ", & " \\
\hline 7 & " & $"$ \\
\hline $\begin{array}{l}8 \\
9\end{array}$ & $"$ & " \\
\hline $\begin{array}{r}9 \\
10\end{array}$ & ", & $"$ \\
\hline 11 & " & ," \\
\hline 12 & , & ", \\
\hline 13 & , & , \\
\hline 14 & , & ", \\
\hline 15 & , & ," \\
\hline $\begin{array}{l}16 \\
17\end{array}$ & , & , \\
\hline 18 & , & ," \\
\hline 19 & , & , \\
\hline 20 & , & ", \\
\hline 21 & , & , \\
\hline 22 & " & , \\
\hline 23 & ," & ", \\
\hline 24 & . & \\
\hline 25 & , & , \\
\hline 26 & , & , \\
\hline 27 & , & " \\
\hline 28 & ", & ", \\
\hline 29 & "' & " \\
\hline $\begin{array}{l}30 \\
31\end{array}$ & $"$ & $"$ \\
\hline 32 & ", & , \\
\hline 33 & , & ," \\
\hline 34 & ,, & \\
\hline
\end{tabular}

\begin{tabular}{|c|c|c|}
\hline $\begin{array}{c}\text { Antitoxic value in } \\
\text { units per c.c. }\end{array}$ & & $\begin{array}{l}\text { rcentage } \\
\text { aily loss }\end{array}$ \\
\hline $\begin{array}{l}8 \cdot 5 \\
4 \cdot 25 \\
3 \cdot 25\end{array}$ & $\begin{array}{l}\overline{50 \cdot 5} \\
23 \cdot 5\end{array}$ & Phase A \\
\hline & & Phase B \\
\hline 1.9 & $23 \cdot 5$ & Averag \\
\hline 1.62 & $14 \cdot 7$ & $21 \cdot 1$ \\
\hline $1 \cdot 25$ & $22 \cdot 8)$ & \\
\hline $0 \cdot 7$ & $44 \cdot 0$ & Phase C \\
\hline $0 \cdot 35$ & $50 \cdot 0$ & Average \\
\hline $0 \cdot 17$ & $51 \cdot 4$ & $48 \cdot 5$ \\
\hline $0 \cdot 12$ & $16 \cdot 0$ & \\
\hline 0.08 & $33 \cdot 3$ & \\
\hline 0.07 & $12 \cdot 5$ & \\
\hline 0.05 & $28 \cdot 6$ & \\
\hline 0.02 & $36 \cdot 8$ & \\
\hline 0.01 & $29 \cdot 3$ & \\
\hline$\overline{0}$ & $\overline{200}$ & Phase D \\
\hline $\begin{array}{l}0 \cdot 0045 \\
0 \cdot 004\end{array}$ & $\begin{array}{l}32 \cdot 9 \\
11.1\end{array}$ & $\begin{array}{c}\text { Average } \\
22.4\end{array}$ \\
\hline $\begin{array}{c}0.004 \\
-\end{array}$ & 11. & \\
\hline - & - & \\
\hline - & 一 & \\
\hline 0.0012 & $21 \cdot 4$ & \\
\hline 0.001 & $8 \cdot 7$ & \\
\hline 一 & - & \\
\hline $0 \cdot 0007$ & $16 \cdot 3$ & \\
\hline 0.0007 & - & \\
\hline - & - & \\
\hline$? 0 \cdot 0005$ & - & \\
\hline
\end{tabular}

In a further experiment a normal rabbit, number 60 , was injected intravenously at daily intervals for three weeks with 1.0 c.c. of normal horse serum, and then five days after the last injection of normal serum received an intravenous injection of diphtheria antitoxic horse serum. The course of elimination of antitoxin from this rabbit is shown in Table XLVI and Curve 82 on Chart XXI. The contrast between this rabbit and number 48 (Table XLIV and Curve 80) is very marked. Rabbit 48 had received a few more injections than rabbit 60 and showed no signs of accelerated loss; rabbit 60 , on the other hand, contained considerable excess precipitin five days after 
the last injection of normal horse serum. Four weeks later rabbit 60 was again injected (see Curve 83). The big loss during the first 24 hours shows that

\section{TABLE XLVI.}

Showing the antitoxic values of three rabbits at different intervals of time, after intravenous injections of 0.5 c.c. of unconcentrated horse serum containing 750 units of diphtheria antitoxin given after a previous series of injections of horse serum.

Rabbit

Previous history

Interval since

last injection

Time

interval

15 minutes

1 day

2 days

3 ,"

4 ,

5 ,

6 ,

7 ,

8 ,

9 ,

10 ,"

11 "

12 ,

13 ,

14 ",

15 ,
60

21 injections of 1.0 c.c. normal horse serum at daily intervals

$$
5 \text { days }
$$

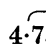

$4 \cdot 75$
$0 \cdot 5$

$0 \cdot 5$
$0 \cdot 14$

0.003

$? 0.0005$

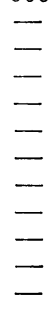

60

22 injections of horse serum at daily intervals

4 weeks
48

30 injections as recorded in Table XLIII

7 weeks
62

34 injections as recorded Table XLV

11 days

Antitoxic value in units per c.c.

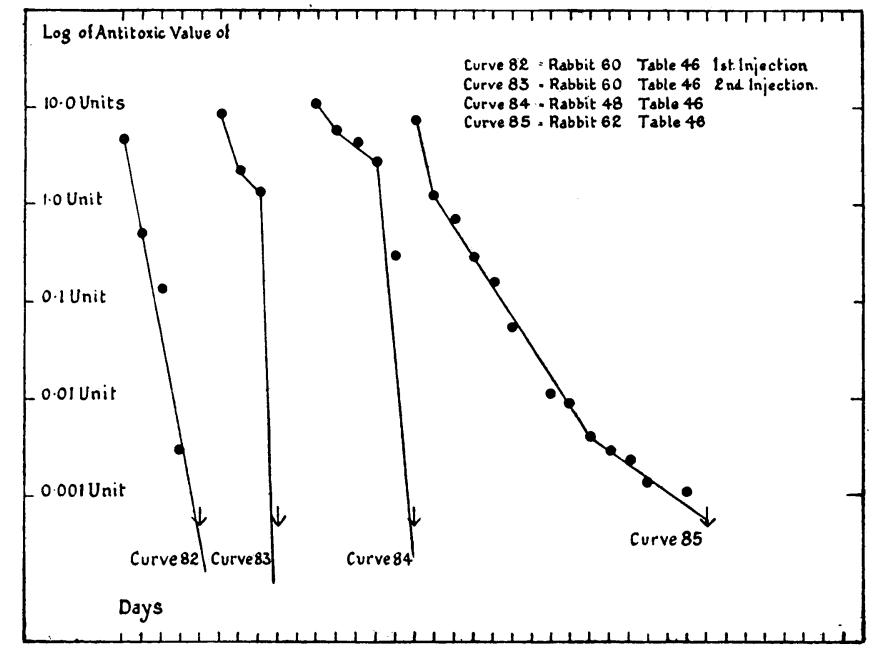

Chart XXI

precipitin was still present, and the general slope of the curve indicates a high degree of active immunity. Tables XLVI and XLVII and Chart XXI also record the results of subsequent injection into rabbits 42 and 62 . Rabbit 48, 
when reinjected seven weeks after the last injection of the series already recorded, showed no indication that precipitin was present at the time of injection, but the early appearance of Phase C in Table XLVII and Curve 84 shows that the rabbit was actively immune. Rabbit 62 , however, when reinjected 11 days after the last injection of the series recorded previously in Table XLV was in a condition of active production of precipitin and for the first nine days Phase $\mathrm{A}$ and Phase $\mathrm{B}$ losses were increased by precipitin. No accelerated loss occurred because the serum injected in the presence of excess precipitin failed to act as an antigen.

\section{TABLE XLVII.}

Showing the percentage daily loss in antitoxic values of three rabbits at different intervals of time, after intravenous injections of 0.5 c.c. of unconcentrated horse serum containing 750 units diphtheria antitoxin given after a previous series of injection of horse serum.

\begin{tabular}{|c|c|c|c|c|c|}
\hline Time int & erval & Rabbit 60 & Rabbit 60 & Rabbit 48 & Rabbit 62 \\
\hline $0-1 d$ & & $89 \cdot 4$ & $73 \cdot 5$ & $47 \cdot 6$ & $83 \cdot 3$ \\
\hline $1-2$ & lays & $72 \cdot 0$ & $39 \cdot 1$ & $22 \cdot 7$ & $44 \cdot 0$ \\
\hline $2-3$ & ,, & $97 \cdot 8$ & $>99.9$ & $35 \cdot 3$ & $57 \cdot 1$ \\
\hline $3-4$ & , & - & - & $89 \cdot 1$ & $46 \cdot 7$ \\
\hline $4-5$ & , & - & - & - & $65 \cdot 7$ \\
\hline $5-6$ & ," & 一 & - & - & - \\
\hline $6-7$ & ," & - & - & - & $55 \cdot 3$ \\
\hline $7-8$ & , & - & - & - & $18 \cdot 2$ \\
\hline $8-9$ & , & - & - & - & $55 \cdot 5$ \\
\hline 9-10 & ," & - & - & - & $25 \cdot 0$ \\
\hline $10-11$ & ," & - & - & - & $26 \cdot 7$ \\
\hline $11-12$ & ," & - & - & - & $35 \cdot 4$ \\
\hline $12-13$ & ," & 一 & - & 一 & - \\
\hline $13-14$ & , & - & - & - & $11 \cdot 4$ \\
\hline $14-15$ & , & - & - & - & - \\
\hline
\end{tabular}

At first sight the three rabbits dealt with in Tables XLIII to XLVII do not give consistent results, but for each variation two explanations are suggested: $(a)$ an antigen may fail as a stimulus to antibody production if given intravenously when excess antibody is present, $(b)$ excess antibody produced by former stimuli may be used up by subsequent injections.

\section{SUMMARY OF PART IV.}

1. There is some evidence that an injection of $0 \cdot 00001$ c.c. of horse serum causes an appreciable degree of active immunity to horse serum in rabbits.

2. Rabbits actively immune to horse serum receiving a series of injections of antitoxic horse serum at intervals of three to ten weeks eliminated the antitoxin at rapidly increasing rates.

3. An intravenous injection of antitoxic horse serum given six weeks after the second of a series of 0.5 c.c. in a rabbit already actively immune to horse serum was eliminated so rapidly owing to excess precipitin that less than $1 / 1000$ th remained 24 hours after injection.

4. Another rabbit which, six days after a previous injection, was given 
serum intravenously, lost over 99 per cent. of the antitoxin within 15 minutes of the injection.

5. The maximum of circulating antitoxin detected after the second subcutaneous injection into a sensitised rabbit was only $1 / 15,000$ th of the amount injected.

6. Antitoxic horse serum injected intravenously into rabbits at weekly intervals was rapidly eliminated and less than 2 per cent. could be detected 24 hours after eaeh injection.

7. After 12 daily intravenous injections of antitoxic horse serum into a rabbit, the antitoxic content was only one-half of that after the first injection; later injections were not eliminated so quickly and precipitin formation gradually ceased.

8. The rate of elimination of antitoxic horse serum in a rabbit may be greatly delayed by daily injections of normal horse serum.

(MS. received for publication 15. vIII. 1923.—Ed.) 